Journal of

$$
\begin{aligned}
& \text { Entreprenuership and } \\
& \text { Project Management } \\
& \text { (JEPM) }
\end{aligned}
$$

INFLUENCE OF INTERNAL MANAGEMENT COMPETENCIES ON PERFORMANCE OF COMMERCIAL HOUSING PROJECTS IN KIAMBU COUNTY, KENYA

Kenneth Kinuthia Kibugi and Dr. Yusuf Muchelule

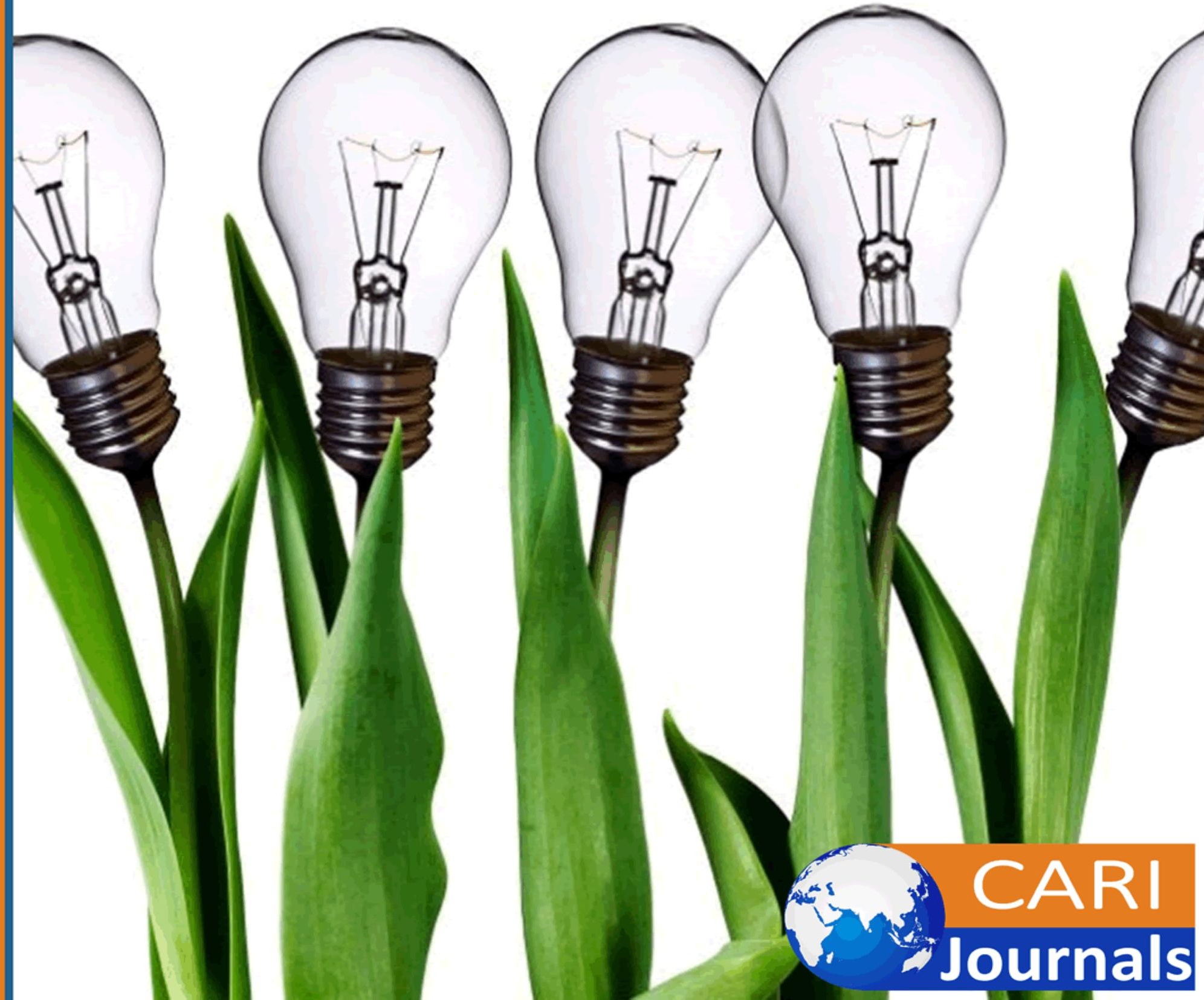




\title{
INFLUENCE OF INTERNAL MANAGEMENT COMPETENCIES ON PERFORMANCE OF COMMERCIAL HOUSING PROJECTS IN KIAMBU COUNTY, KENYA
}

\author{
Kenneth Kinuthia Kibugi \\ Post graduate, Human Resource Development, Jomo Kenyatta University of Agriculture And \\ Technology \\ Corresponding Authors Email: kennethkibugi@gmail.com \\ Dr. Yusuf Muchelule \\ Lecturer, Entrepreurship Procurement and Management \\ Jomo Kenyatta University of Agriculture and Technology
}

\begin{abstract}
Purpose: The objective of the study was to establish the effect of internal management competencies on performance of commercial housing projects in Kiambu County, Kenya.

Methodology: The study employed descriptive research design. There are a total of 100 commercial housing developers operating in Kiambu County. This study targeted owners and operation managers in all the companies. Therefore, the study population was 200 respondents. This study adopted a census approach since the target population is not large. Primary data was collected through a questionnaire. Quantitative data gathered from correctly filled questionnaires was coded; tabulated and analyzed using SPSS version 20 by both descriptive statistics which included mean and standard deviation and inferential statistics which includes Pearson correlation and regression coefficient which was used. The data was presented using frequency tables and graphs.
\end{abstract}

Results: The study revealed that there was a positive association between the variables of the study, that is, leadership competency, financial competency, project consultant competency and information technology competency with coefficients $0.636,0.645,0.676$ and 0.622 respectively in relation to performance of commercial housing projects in Kiambu County. The p-values of leadership competency, financial competency, project consultant competency and information technology competency were $0.001,0.011,0.000$ and 0.014 respectively. This implied that there was a significant and positive relation between internal management competencies and performance of commercial housing projects in Kiambu County.

Unique contribution to theory, policy and practice: The commercial housing firms should adopt the various strategic competencies that are useful to an organization to boost the performance of projects in commercial housing. The competencies include leadership and top management skills and financial management. The modern technology in the IT field is useful and should be adopted in the various project firms. Commercial housing firms' excellence in internal management and acquisition of necessary physical and human resources should be an aim for all the registered firms. This is necessary to ensure quality of the projects. 
Journal of Entrepreneurship and Project Management

ISSSN 2520-9116 (Online)

Vol.6, Issue No.1, pp $1-23,2021$

$\underline{\text { www.carijournals.org }}$

Key words: management competencies, housing projects, firm competencies, leadership competency, financial competency.

\section{INTRODUCTION}

Project management is the discipline of organizing and managing resources in such a way that these resources deliver all the work required to complete a project within defined scope, time, and cost constraints. Effective project management is important for the successful accomplishment of projects. Kerzner and Kerzner (2017) suggest that the factors of success in project management include commitment to complete the project, appointment of a skilled project manager, adequate definition of the project, correctly planning the activities in the project, adequate information flow, accommodation of frequent changes, rewarding the employees, and being open to innovations. The environment in which the project takes place was also taken into account by many researchers. That the use of the appropriate management competencies contributes to successful project performance is also stressed by many researchers (Heldman, 2015).

A project being a series of interrelated set of activities that has a definite start and ending point and results in the accomplishment of unique often major outcome, its characterized to involve tracking individual performance, providing feedback, resolving issues and coordinating changes to enhance overall project performance (Wangeci, 2013). A project is considered totally successful if it gets completed on time, within budget and performs exactly the designed specifications but this is totally out of order as many projects don't meet the requirements. And this majorly depends on internal competencies of the organization.

The required project management skills can include: communication and feedback systems, quality, safety, risk and a conflict management system, supervisory skills, experience, coordination and leadership, communication skills, organizational structures, control mechanisms of subcontractors' works, and the overall managerial actions in planning, organizing, leading and controlling (Heagney, 2016). Turner (2016), states that the management needs to be involved in the up-front planning efforts and effectiveness of communication, control system, management system and organizational culture. Project work grouped together in form of internal competencies promotes successful management of that work in order to achieve strategic business performance and goals achievement.

Major consideration is given to the planning management and the execution of the target set; that is, the management and monitoring activities concerning the three main construction targets, which are time limit, efficiency, and cost. (Dainty et al, 2004) alludes that the management capability and expertise reserve of the developer project manager (hereinafter alluded to as the program manager) would have a direct impact on the project effectiveness as the central figure of the temporary organization and the construction management practices.

The term competence dates back to the 1980s, with one stream originated in the United States called attribute-based competency approach, and another stream called performance-based competency approach initiated in the United Kingdom (Crawford, 2005). The first approach defines competence as a combination of knowledge, skills and personal characteristics, based on the agreement of Succar et al. (2013). The second stream describes competence as what employees 
Journal of Entrepreneurship and Project Management

ISSSN 2520-9116 (Online)

Vol.6, Issue No.1, pp $1-23,2021$

$\underline{\text { www.carijournals.org }}$

are expected to do according to a required performance level (Young \& Conboy, 2013). Finally, there are several world known project management competence standards that recognize this requirements, for example the Project Management Body of Knowledge, the Project Manager Competency Development Framework, the IPMA Competence Baseline and the APM Competence Framework. Krajewski, Malhotra and Ritzman (2015) applied the concept of competency to managers and defined competency as an underlying characteristic of a person, including motives, traits, and skills, aspects of one's self-image or social role, or a body of knowledge which he or she uses.

Professional competency in project management (PM) has been addressed by a number of research studies which are primarily based on the opinions of project management practitioners. In some studies they have highlighted the significance of PM skills and characteristics in project success (Starkweather, \& Stevenson, 2011), while others have assessed PM competencies across cultures and industries (Stevenson, \& Starkweather, 2010). In other studies which have been conducted on project managers' competencies focused more specifically on the importance of human skills. Larson and Gray (2013) indicated that successful project managers should recognize the importance of managing people in projects by applying good interpersonal skills.

Project measurement is the process of evaluating performance relative to a defined goal. It provides a sense of where we are and more importantly where we are going and measurement can be used to guide steady and advancement towards established goals and identify short falls or stagnation. Project performance means different things to different people (Ahsan, Ho \& Khan, 2013). Zhang, Zuo and Zillante (2013) views project performance as satisfying project objectives, that is, time, cost and quality and safety. Bredin and Söderlund (2013) noted that project performance involves both meeting customer expectations and getting the job done within the commonly accepted constraints of time, cost and quality. Bredin, and Söderlund suggests that project management can be defined as successful when it has achieved the project objectives, within time, within cost at the defined performance level while utilizing the assigned resources effectively and efficiently.

Housing has a central importance to quality of life with considerable economic, social, cultural and personal significance. Though a country's national prosperity is usually measured in economic terms, increasing wealth is of diminished value unless all can share its benefits and if the growing wealth is not used to redress growing social deficiencies, one of which is housing (Amoatey, et al., 2015). Housing plays a huge role in revitalizing economic growth in any country, with shelter being among key indicators of development (Ireri, 2010). The universal declaration of human rights gives one of the basic human rights as the right to a decent standard of living, central to which is the access to adequate housing (United Nations, The Human Rights article 25, 1948). Housing as a basic human right demands that urban dwellers should have access to decent housing, defined as one that provides a foundation for, rather than being a barrier to, good physical and mental health, personal development and the fulfillment of life objectives.

\section{Statement of the problem}

The Kenya National Bureau of Statistics (KNBS) has estimated the Kenyan growth population at $4.2 \%$ and is expected to reach 50 million by 2020. Based on these estimates there is an annual demand of 206,000 units of houses and the current supply is 50,000 units per year which creates a 
Journal of Entrepreneurship and Project Management

ISSSN 2520-9116 (Online)

Vol.6, Issue No.1, pp $1-23,2021$

$\underline{\text { www.carijournals.org }}$

shortfall of 156,000 units every year (KNBS, 2013). (HASS, 2013) suggest that in Kenya the gap between demand and supply for housing continues to grow with the estimated housing demand in urban areas at approximately 150,000 units per year yet the current supply is about 30,000 units. The government of Kenya seeks to march the supply of houses to the existing demand by 2030 (RoK, 2005). Ministry of Housing, Land and Urban Development (2011) reported that $48 \%$ of construction projects in Nairobi County are still incomplete and $10 \%$ of these projects have completely stalled leading to a slow uptake of housing projects. Failure of these construction projects results in reduced supply of quality houses negatively impacting on the economy (GOK, 2003). Housing has been universally accepted as the second most important essential human need, after food. Housing, in all its ramifications, is more than mere shelter since it embraces all the social services and utilities that go to make a community or neighborhood a livable environment.

In Kenya housing construction industry is faced by enormous challenges in quality assurance from cases of collapsing buildings, unfinished and substandard constructed and uninspected houses. Kibuchi and Muchungu (2012) alluded that despite the high quality of training of consultants and regulation of the building industry especially in major urban areas, the intended construction projects do not always meet their goals. Edmonds (2010) has indicated that, a project success is hinged on the skills and competencies of the project manager and the project team. Housing constructions have been pending completion due to management associated delays. The inappropriate cross-checking of the conditions in construction are associated with the management challenges within the housing construction industry and project management (Ambale, Githui \& Omurwa, 2019). This is also manifested by myriad projects that have cost overrun, delayed completion period and poor quality resulting to collapsed buildings in various parts of the country. Along with high maintenance costs, dissatisfied clients and constructions of buildings which are not functional. (Mambo, 2013) concludes that the collapse of buildings in Kiambu town between 2009 and 2010 was attributed to incompetency.

In an attempt to conceptualizing housing construction firms' project management and internal management competencies, this study dwells on the conceptual relationship of the two variables. Nonetheless, to the best knowledge of the researcher, no study has focused on the influence of internal management competencies on performance of commercial housing projects in Kiambu County, Kenya. Thus, this study seeks to fill the existing research gaps, which are both contextual and conceptual in nature. Contextual in the fact that no study has focused on performance of commercial housing projects in Kiambu County and conceptual in the fact no study has concentrated on the four internal management competences (leadership, financial, project consultants and information technology) and how they impact on performance of commercial housing projects. Therefore, this study aims at establishing the influence of internal management competencies on performance of commercial housing projects in Kiambu County.

\section{General objective of the study}

The general objective of this study is to establish the influence of internal management competencies on performance of commercial housing projects in Kiambu County, Kenya 
Journal of Entrepreneurship and Project Management

ISSSN 2520-9116 (Online)

Vol.6, Issue No.1, pp $1-23,2021$

$\underline{\text { www.carijournals.org }}$

\section{Specific objectives of the study}

i. To assess the influence of leadership competency on performance of commercial housing projects in Kiambu County, Kenya

ii. To determine the influence of financial competency on performance of commercial housing projects in Kiambu County, Kenya

iii. To analyze the influence of project consultants competency performance of commercial housing projects in Kiambu County, Kenya

iv. To examine the influence of information technology competency on performance of commercial housing projects in Kiambu County, Kenya

\section{LITERATURE REVIEW}

\section{Theoretical Review}

\section{Project Management Competency Theory}

The work of McClelland \& McBer (1980) established the competence theory. The authors defined competency as the underlying characteristic of an individual that is causally related to criterionreferenced effective and/or superior performance in a job or situation. Since then a number of competency frameworks have been developed by different project management institutes. Crawford (as cited in Boyatzis, 1982 \& Spencer, 1993), puts a model of competence that integrates knowledge, skills, demonstrable performance, and core personality characteristics, noting the last, personality characteristics, as challenging to develop and assess through training. She argues that two of the most influential project management standards, the PMBOK, address only the knowledge aspect of competence while a third, Australia's National Competency Standards, draws from knowledge but focuses only on demonstrable performance.

Previous management studies have investigated the impact of competency on performance. Dainty,(2004) have argued for a competency based performance model for construction project managers where managerial behavior input is appraised and nine performance indicators for PM competency are developed to comprise team building, leadership, decision-making, mutuality and approachability, honesty and integrity, communication, learning, understanding and application, self-efficacy, and maintenance of external relations. In the context of construction project management; it is assumed that if the project manager and the project team have all the required competence for the work then the project implementation is successful. The theory posit that for performance of the full activities required to promote and implement housing projects, project consultant need to have and integrate knowledge, skills, demonstrable performance, and core personality characteristics deeming the theory relevant to this study.

\section{The Technology Acceptance Model}

Technology Acceptance Model was proposed by (Davis, 1989). Emerging information technology cannot deliver improved organizational effectiveness if it is not accepted and used by potential users. Technology Acceptance Model (TAM) is one of the most successful measurements for computer usage effectively among practitioners and academics. TAM is consistent with (Rogers, 1983) theory on diffusion of innovation where technology adoption is a function of a variety of factors including, relative advantage and ease of use. 
Journal of Entrepreneurship and Project Management

ISSSN 2520-9116 (Online)

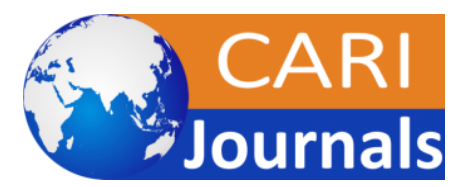

Vol.6, Issue No.1, pp $1-23,2021$

WWW.carijournals.org

Two particular beliefs are addressed through TAM; perceived usefulness and perceived ease of use. Perceived usefulness is defined as being the degree to which a person believes that the use of a system will improve his performance. Perceived ease of use refers to the degree to which a person believes that the use of a system will be effortless. TAM attempts not only for prediction but also for explanation to help researchers and practitioners identify why a particular system may be unacceptable and pursue appropriate steps for use (Larson \& Gray, 2013). The theory is relevant to this study because being in the information era technology can deliver in improved organizational effectiveness, since it has perceived usefulness and perceived ease of use. Information Technology is helpful in the performance of the housing projects in terms of increasing the market value and research that adds more essential information.

\section{Empirical Review}

Chandra (2017) evaluated whether project management competencies influence the project performance. The research was conducted at Philips Healthcare and the research units investigated were the project managers in the markets of India and China. The empirical results revealed a significant relationship between hard skill-scope management and soft skill-negotiation. The results also showed a significant relationship between hard skill-human resource management and soft skill-team building. Further, the results showed that the regression model for this relationship was not significant due to soft and hard skill showing high multicollinearity due to significant correlation between the hard and soft skill.

Jha and Iyer (2016) examined the critical factors affecting quality performance in construction projects. The critical success factors obtained were found to include, project manager's competence; top management's support; monitoring and feedback by project participants; interaction among project participants; and owners' competence. The factors that adversely affected the quality performances of projects included conflict among project participants; hostile socio-economic environment; harsh climatic condition; PM's ignorance \& lack of knowledge; faulty project conceptualization; and aggressive competition during tendering. Analyses also led to the conclusion that the extent of contribution of various success factors varies with the current performance ratings of the project. Project manager's competence and top management support are found to contribute significantly in enhancing the quality performance of a construction project.

Mwambia, (2014) conducted a study on the effect of financial literacy on financial returns of Miraa farmers in Meru county. Descriptive research design was adopted by the study. The target population constituted the Miraa farmers in Igembe, the main Miraa growing area. The study adopted descriptive survey technique. The data collected was analyzed using SPSS version 21 and the significance of the results tested at $95 \%$ using ANOVA, and other statistical inference techniques like Z-tests, T-test and F-tests. The study found that financial literacy levels remained low among the Miraa farmers and this resulted to low returns.

Munyoki (2014) study sought to identify factors influencing completion of construction projects. The study objectives included; contract duration, project financing, planning and supervision/inspection. The research design was a descriptive and explorative or correlative. The findings showed that project cost increased with an average of $13.5 \%$ while project duration 
Journal of Entrepreneurship and Project Management

ISSSN 2520-9116 (Online)

Vol.6, Issue No.1, pp $1-23,2021$

$\underline{\text { www.carijournals.org }}$

increased by $33.6 \% .98 \%$ of respondents believe project financing and inspection/supervision influenced greatly completion of construction projects. $73 \%$ and $71 \%$ respectively gave the information that construction contract duration and project delivery type chosen respectively influence completion of construction projects. $100 \%$ of the respondents believe project planning at all stages influences completion of construction projects. The majority respondents said EPC/Turnkey projects are the most successful in ensuring project completion though the type of project delivery chosen may vary for various reasons.

Mwai (2014) focused on four factors that have a great influence on the successful completion of property development projects: project management, finance, consultants and the contractor. The study aimed to establish how each of these factors influences project completion. The research relied both on primary and secondary data. The results of the regression equation showed that for a point increase in the independent variables, successful completion of development projects is predicted to increase by 4.441 , given that all the other factors are held constant. The research findings also indicated that there was a very strong positive relationship $(R=0.852)$ between the variables. It was revealed that $72.7 \%$ of successful completion of property development projects could be explained by the factors under study. From this study it is evident that at $95 \%$ confidence level, the variables produce statistically significant values and can be relied on explain to successful completion of development projects.

Gruden, and Stare (2018), conducted a study to raise awareness of the value of behavioral competencies of project managers. The study adopted quantitative survey to identify the importance and influence of consultancy competencies on efficient project performance. The study was also interested to learn whether or not managers are aware of the importance of consultant's competencies and which competence they consider to be the most crucial of all. Data were collected via a web-based questionnaire in which respondents evaluated levels of behavioral competencies, reported on the performance of projects in their enterprises, and provided opinions on the competencies' importance. Regression analysis identified the most influential competencies and verified the overall impact of behavioral consultant competencies on project performance. As shown by the research, the most important competence was project manager assertiveness.

Ogero (2014) in his study sought to establish the influence of Project Management Information System on project performance in the construction industry; a case of Nairobi County, Kenya. The study focused on the system, quality information, the system user and the system use on performance of construction projects. A descriptive research design was adopted. The four independent variables were (the system, quality of information, the system user and the system use) were found to have a strong and positive correlation with the dependent variable (project performance). The research also found out that the use of the system to generate quality information needed by the user (project manager) to perform project tasks greatly helped them to perform their tasks in a more professional manner thus increasing the performance of the project. It was therefore concluded that the use of Project Management Information System helped in the improving performance of project while respecting the projects constraints of time, budget and quality specification while meeting the project objectives.

Hawajreh and Sharabati (2012) investigated the influence of Technology Information (IT) on Knowledge Management Practices (KMP) in Jordanian Industrial Companies (JICs). Practical 
data were collected from 206 companies out of 1242 companies by means of a questionnaire. Cronbach's Alpha was used to test reliability, and multiple regressions analysis was employed to test hypotheses. The results of the study indicated that there was a positive significant relationship between information technology and knowledge management practices. Information technology and knowledge management practices are important source of organizations' wealth and therefore it should be taken into serious consideration when formulating the company's strategy.

\section{RESEARCH METHODOLOGY}

The study used a descriptive research design. The use of descriptive research design is justifiable since it offers the study an opportunity to collect data from project managers and project consultants and empirically test the relationship of the constructs along its conceptualization of internal competencies on project performance in housing projects, Kiambu County, Kenya. The study population for this study was all the registered commercial housing developers in Kenya. This study adopted a census approach since the target population is not large. Therefore, all the 200 respondents ( 2 from each company) constituted the sample size. The main research instrument used in this study was a questionnaire. Primary data was collected using the well-structured questionnaires that were administered to the selected respondents who were the operation managers of the companies.

Quantitative data gathered from correctly filled questionnaires was coded, tabulated and analyzed using SPSS version 20 by both descriptive statistics which include mean and standard deviation to capture the characteristics of the variables under study and inferential statistics which include Pearson correlation and regression coefficient which were used to analyze the relationship of the dependent and the independent variables. The findings from the analyzed data were presented using frequency tables and figures.

\section{RESEARCH FINDINGS \\ Demographic information}

From the findings, the Majority (57\%) of the respondents were undergraduates, $21 \%$ had attained a secondary school certificate, and $12 \%$ were post graduates whereas $10 \%$ had only attained a primary school certificate. 
Journal of Entrepreneurship and Project Management

ISSSN 2520-9116 (Online)

Vol.6, Issue No.1, pp 1 - 23, 2021

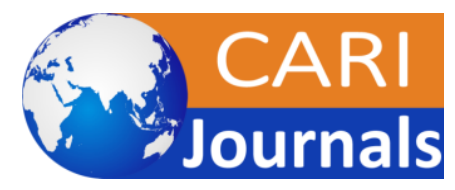

WWW.carijournals.org

\section{Education}

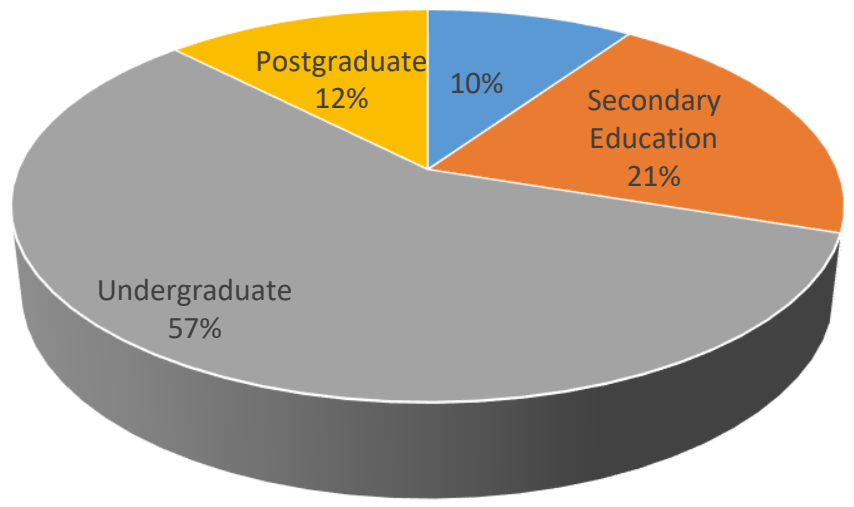

- - Secondary Education - Undergraduate - Postgraduate

\section{Figure 1 Education level}

The results reveal that most of the housing commercial firms (46\%) have been in operation for 6 to 10 years. $43 \%$ of the respondents revealed further that the firms have been in operation for more than 10 years whereas $11 \%$ housing commercial firms have been in operation for less than 5 years.

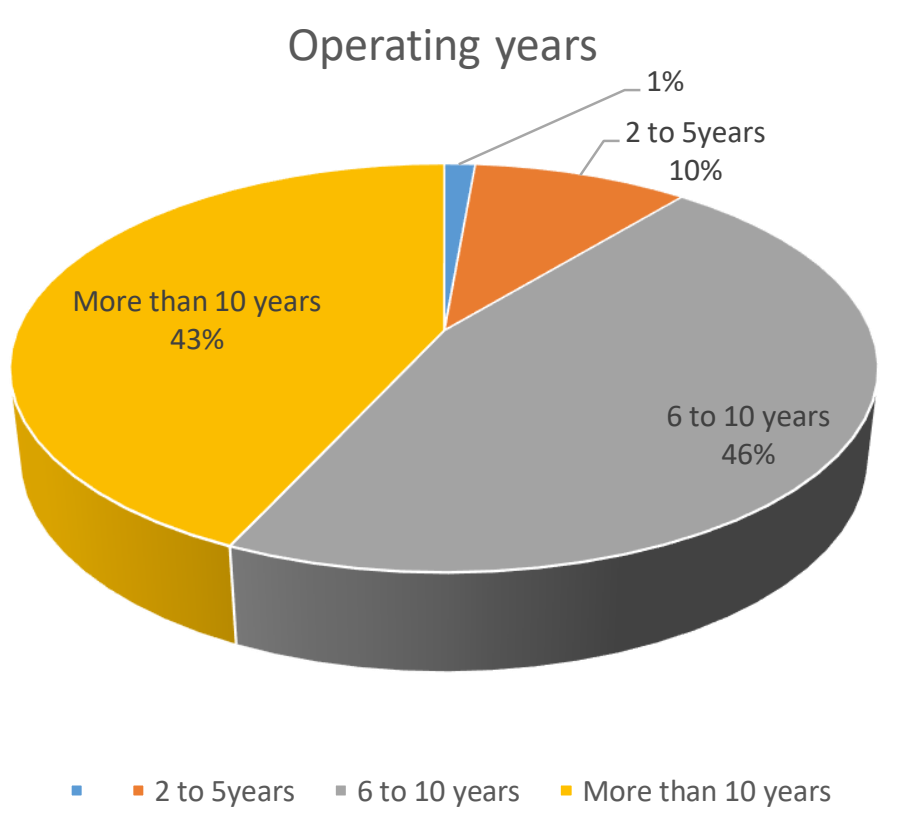


Journal of Entrepreneurship and Project Management

ISSSN 2520-9116 (Online)

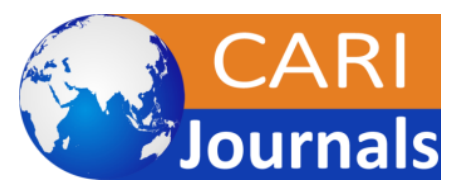

Vol.6, Issue No.1, pp $1-23,2021$

WWW.carijournals.org

\section{Figure 2 Years of Operation}

Majority (61\%) of the respondents in the survey were owner and 39\% were operation managers in the various firms.

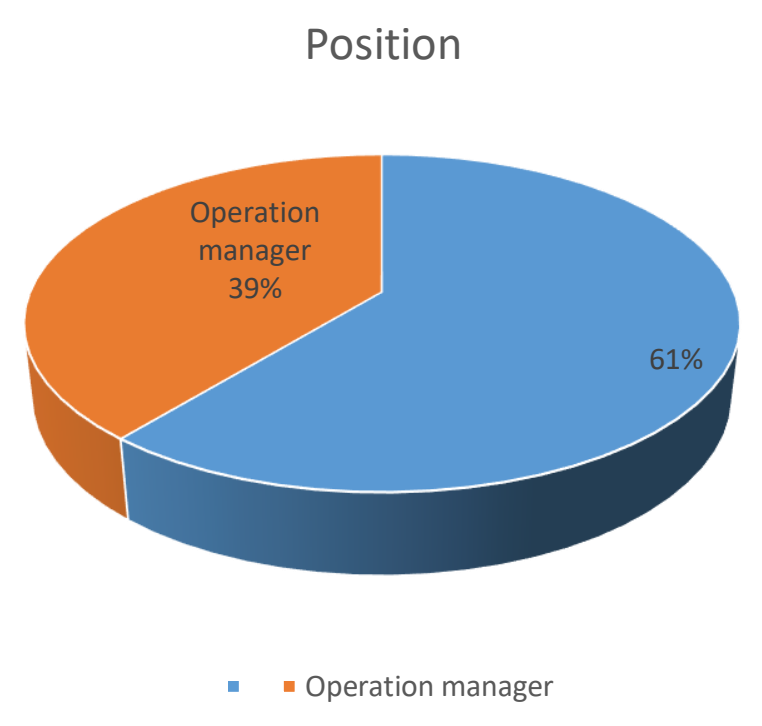

Figure 3 Position in the firms

Internal management competencies on performance of commercial housing project

Table 1 Leadership Competency

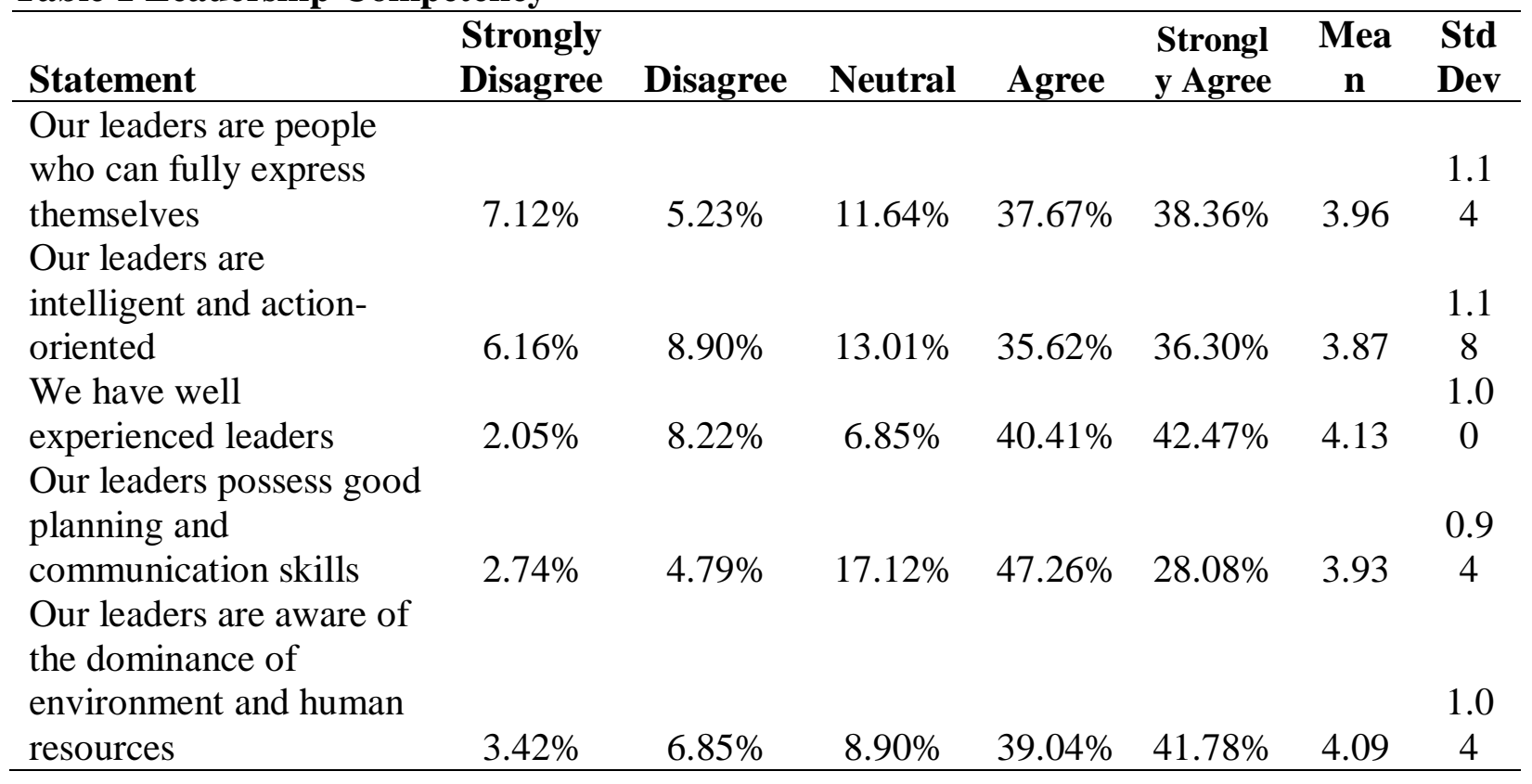


Journal of Entrepreneurship and Project Management

ISSSN 2520-9116 (Online)

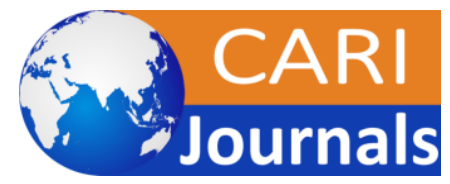

Vol.6, Issue No.1, pp $1-23,2021$

WWW.carijournals.org

Aggregate

4.006

majority (76\%) of the respondents were in agreement with the statement that leaders in the various commercial housing project firms are people who can fully express themselves to demonstrate leadership competency. $12 \%$ of the respondents were had a neutral opinion over the issue whereas $12 \%$ of them disagreed with the statement. Most of the survey participants (72\%) were in agreement with the statement that leaders are intelligent and action-oriented in the project firms, $13 \%$ of the respondents had a neutral opinion whereas a number of them (15\%) disagreed with the statement. The opinion on whether the commercial housing project firms have well experienced leaders was agreed upon by most of the respondents (83\%), $7 \%$ were in a neutral opinion whereas $10 \%$ of them disagreed over the opinion. The statement that leaders possess good planning and communication skills in the commercial housing project firms was agreed on by majority (75\%), a number of them $(17 \%)$ had no opinion whereas $8 \%$ disagreed with the statement. Majority $(81 \%)$ of the respondents agreed with the statement that in the various project firms leaders are aware of the dominance of environment and human resources, $9 \%$ had a neutral opinion whereas $10 \%$ of the respondents disagreed. The aggregate mean and standard deviation of the responses were 4.00 and 1.06 respectively. This implies a high mean and a small standard deviation which shows the uniformity of the data collected in the study. The study findings were similar to Kiioh (2015) who identified four aspects of leadership which included skills, experience, control and style and investigated their influence on performance of IT projects at Fintech Kenya. The findings illustrated that leadership style influenced performance of IT projects at a very great extent. The study concluded that there was a significant relationship between project management leadership aspects and performance of IT projects.

Financial Competency

Table 2 Financial Competency

\begin{tabular}{|c|c|c|c|c|c|c|c|}
\hline Statement & $\begin{array}{l}\text { Strongly } \\
\text { Disagree }\end{array}$ & $\begin{array}{c}\text { Disagre } \\
\text { e }\end{array}$ & $\begin{array}{c}\text { Neutra } \\
l\end{array}$ & Agree & $\begin{array}{l}\text { Strongl } \\
\qquad \begin{array}{c}\mathbf{y} \\
\text { Agree }\end{array} \\
\end{array}$ & $\begin{array}{c}\text { Mea } \\
\mathbf{n}\end{array}$ & $\begin{array}{l}\text { Std } \\
\text { Dev }\end{array}$ \\
\hline $\begin{array}{l}\text { Our financial matters in } \\
\text { our organization always } \\
\text { offers alternatives that do } \\
\text { mitigate risks }\end{array}$ & $4.11 \%$ & $5.48 \%$ & $9.59 \%$ & $\begin{array}{c}40.41 \\
\%\end{array}$ & $40.41 \%$ & 4.08 & 1.04 \\
\hline $\begin{array}{l}\text { We always involve cost } \\
\text { control methods in our } \\
\text { projects }\end{array}$ & $8.22 \%$ & $4.11 \%$ & $9.59 \%$ & $\begin{array}{c}41.78 \\
\%\end{array}$ & $36.30 \%$ & 3.94 & 1.17 \\
\hline $\begin{array}{l}\text { Our consultants have } \\
\text { financial literacy } \\
\text { knowledge }\end{array}$ & $4.79 \%$ & $5.48 \%$ & $11.64 \%$ & $\begin{array}{c}38.36 \\
\%\end{array}$ & $39.73 \%$ & 4.03 & 1.08 \\
\hline
\end{tabular}


Journal of Entrepreneurship and Project Management

ISSSN 2520-9116 (Online)

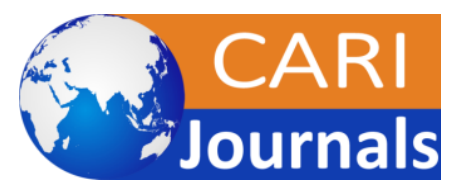

Vol.6, Issue No.1, pp 1 - 23, 2021

www.carijournals.org

We are able to control our

assets leading to a high

performance

$7.53 \%$

$6.85 \%$

$12.33 \%$

34.25

Our firm factors a

contingency amount in

the budget

$2.74 \% \quad 6.85 \% \quad 9.59 \%$

39.04

Aggregate

$\% \quad 41.78 \%$

$4.1 \quad 1.02$

4.01 1.10

the majority of the respondents $(81 \%)$ were on agreement with the statement that financial matters in the various commercial housing project firms always offers alternatives that do mitigate risks, however, $10 \%$ were undecided whereas $9 \%$ disagreed with the statement. An opinion was taken on adoption and involvement of cost control methods in the projects where $78 \%$ of the survey participants agreed with the opinion, $10 \%$ had a neutral opinion whereas $12 \%$ disagreed. Most of the respondents $(79 \%)$ agreed, $12 \%$ were undecided whereas $9 \%$ disagreed with the statement that consultants have financial literacy knowledge in their operations. On the opinion whether commercial housing firms are able to control our assets leading to a high performance was collected and the most of the respondents $(73 \%)$ were on agreement with the statement, $12 \%$ were undecided whereas $15 \%$ disagreed. Majority of the respondents $(81 \%)$ agreed with the statement that the various project firms factor a contingency amount in their budget, $10 \%$ had a neutral opinion whereas $9 \%$ disagreed with the statement. The average of the mean and the standard deviation was 4.01 and 1.1 respectively. This implied that the financial competency practices are applied in majority of the commercial housing projects firms. The findings concurred with Munyoki (2014) who revealed that project planning at all stages influences completion of construction projects. Further, EPC/Turnkey projects are the most successful in their practice of ensuring project completion. However, the type of project delivery chosen may vary due to the various strategies used in different firms.

\section{Project Consultant Competency}

Table 3 Project Consultant Competency

\begin{tabular}{|c|c|c|c|c|c|c|c|}
\hline Statement & $\begin{array}{l}\text { Strongly } \\
\text { Disagree }\end{array}$ & $\begin{array}{c}\text { Disagre } \\
\mathrm{e}\end{array}$ & Neutral & Agree & $\begin{array}{l}\text { Strongl } \\
\text { y Agree }\end{array}$ & Mean & $\begin{array}{l}\text { Std } \\
\text { Dev }\end{array}$ \\
\hline \multicolumn{8}{|l|}{ Our project managers have } \\
\hline the required consultancy & & & & 36.30 & & & \\
\hline competence & $8.90 \%$ & $6.85 \%$ & $16.44 \%$ & $\%$ & $31.51 \%$ & 3.75 & 1.23 \\
\hline $\begin{array}{l}\text { Our consultants perform } \\
\text { effectively leading to }\end{array}$ & & & & & & & \\
\hline success in our projects and & & & & 40.41 & & & \\
\hline organizations & $6.85 \%$ & $6.85 \%$ & $21.23 \%$ & $\%$ & $24.66 \%$ & 3.69 & 1.12 \\
\hline $\begin{array}{l}\text { Our consultants consistently } \\
\text { supervise the projects to }\end{array}$ & & & & 37.67 & & & \\
\hline monitor progress & $3.42 \%$ & $8.90 \%$ & $9.59 \%$ & $\%$ & $40.41 \%$ & 4.03 & 1.08 \\
\hline
\end{tabular}


Journal of Entrepreneurship and Project Management

ISSSN 2520-9116 (Online)

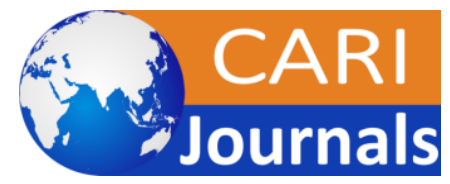

Vol.6, Issue No.1, pp 1 - 23, 2021

www.carijournals.org

Our consultants are able to

draw and design the projects

Our consultant are well

versed with building

technology knowledge
$1.37 \%$

$8.22 \%$

$10.27 \%$

43.84

$\%$

$36.30 \%$

4.05

0.96

41.10

Aggregate

$6.85 \%$

$4.79 \%$

$13.70 \%$

$33.56 \%$

3.90

1.13

$3.884 \quad 1.104$

The majority of the respondents (68\%) were in agreement that project managers, be it owners or operational managers, have the required consultancy competence, $17 \%$ had a neutral opinion whereas $15 \%$ disagreed. The opinion on whether consultants perform effectively leading to success in their projects and organizations was assessed and majority of the respondents $(65 \%)$ were in the agreement with the statement, $21 \%$ had a neutral opinion while $14 \%$ disagreed. There was a massive agreement (78\%) over the statement that the consultants consistently supervise the projects to monitor progress, $10 \%$ recorded a neutral opinion whereas $12 \%$ disagreed with the statement. Majority of the survey participants $(80 \%)$ were of the opinion that consultants are able to draw and design the projects effectively, $10 \%$ were undecided whereas another $10 \%$ disagreed with the statement. Majority $(76 \%)$ agreed with the statement that consultants are well versed with building technology knowledge, $14 \%$ were undecided while $12 \%$ were on disagreement with the issue. The average mean was high at 3.884 and the standard deviation was low at 1.104 indicating the uniformity of the collected results.

\section{Information Technology Competency}

Table 4 Information Technology Competency

\begin{tabular}{|c|c|c|c|c|c|c|c|}
\hline Statement & $\begin{array}{l}\text { Strongly } \\
\text { Disagree }\end{array}$ & Disagree & Neutral & Agree & $\begin{array}{l}\text { Strongl } \\
\text { y Agree }\end{array}$ & Mean & $\begin{array}{l}\text { Std } \\
\text { Dev }\end{array}$ \\
\hline $\begin{array}{l}\text { Our managers are well } \\
\text { informed about their } \\
\text { technology portfolio }\end{array}$ & $9.59 \%$ & $5.48 \%$ & $13.70 \%$ & $38.36 \%$ & $32.88 \%$ & 3.79 & 1.23 \\
\hline $\begin{array}{l}\text { Our consultants are } \\
\text { innovative thinkers }\end{array}$ & $5.48 \%$ & $8.90 \%$ & $16.44 \%$ & $37.67 \%$ & $31.51 \%$ & 3.81 & 1.14 \\
\hline $\begin{array}{l}\text { We have adopted an easy } \\
\text { to use information } \\
\text { technology } \\
\text { Our managers have }\end{array}$ & $6.85 \%$ & $6.85 \%$ & $13.70 \%$ & $47.95 \%$ & $24.66 \%$ & 3.77 & 1.11 \\
\hline $\begin{array}{l}\text { knowledge about novel IT, } \\
\text { enabling effective IT } \\
\text { decisions making } \\
\text { We have a system to } \\
\text { generate quality }\end{array}$ & $4.79 \%$ & $5.48 \%$ & $15.07 \%$ & $46.58 \%$ & $28.08 \%$ & 3.88 & 1.04 \\
\hline $\begin{array}{l}\text { information needed by our } \\
\text { project Managers } \\
\text { Aggregate }\end{array}$ & $6.16 \%$ & $6.85 \%$ & $13.01 \%$ & $34.93 \%$ & $39.04 \%$ & $\begin{array}{l}3.94 \\
\mathbf{3 . 8 4}\end{array}$ & $\begin{array}{l}1.16 \\
\mathbf{1 . 1 4}\end{array}$ \\
\hline
\end{tabular}

The findings in Table 4.5 shows that majority of the respondents $(71 \%)$ were of the agreement with the statement that managers are well informed about their technology portfolio in the 
commercial housing project organizations, $14 \%$ were undecided whereas $15 \%$ disagreed. Most of the respondents $(70 \%)$ were in agreement with the statement that consultants are innovative thinkers, $16 \%$ had a neutral opinion whereas $14 \%$ disagreed with the statement. An opinion on whether the commercial housing project organizations have adopted an easy to use information technology was agreed on by the majority (73\%), 14\% had a neutral opinion while $13 \%$ disagreed. A survey on whether managers have knowledge about novel IT, enabling effective IT decisions making had different opinion with majority agreeing, undecided and some disagreeing with $75 \%$, $15 \%$ and $10 \%$ respectively. The opinion on whether the organizations have a system to generate quality information needed by their project Managers was agreed on by majority at $74 \%, 13 \%$ were undecided whereas $13 \%$ disagreed with the statement. The average mean and the standard deviation was 3.84 and 1.14 respectively. The high mean and low standard deviation revealed that the results were uniform. The results concurred with Hawajreh and Sharabati (2012) who indicated that there was a positive significant relationship between information technology and knowledge management practices. Information technology and knowledge management practices are important source of organizations' wealth and therefore it should be taken into serious consideration when formulating the company's strategy.

\section{Correlation Analysis}

Table 5 Correlation coefficients

$\begin{array}{ccccc} & \text { Financial } & & \text { Information } & \\ \text { Leadership } & \text { Competen } & \text { Project Consultant } & \text { Technology } & \\ \text { Competency } & \text { cy } & \text { Competency } & \text { Competency } & \text { Performance }\end{array}$

Leadership Pearson

Competency Correlation 1

Sig. (2-

Tailed)

$\mathrm{N} \quad 147$

Financial Pearson

Competency Correlation $.508^{* *} \quad 1$

Sig. (2-

Tailed) $\quad 0.000$

$\mathrm{N} \quad 147 \quad 147$

Project

Consultant Pearson

Competency Correlation $.340^{* *} \quad .393^{* *} \quad 1$ 
Journal of Entrepreneurship and Project Management

ISSSN 2520-9116 (Online)

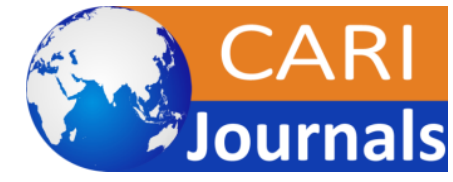

Vol.6, Issue No.1, pp $1-23,2021$

WWW.carijournals.org

Sig.

Tailed)

$\mathrm{N}$

Information

Technology

Competency

Sig

$(2-$

Tailed)

$\mathrm{N}$

Pearson

Performance

Pearson

Correlation

Correlation
0.000

147

$.503 * *$

0.000

0.000

0.000

147

147

147

147

Sig.

Tailed)

(2-

$\mathrm{N}$
$.636^{* *}$

0.000

0.000

0.000

146
147

$146 \quad 146 \quad 146$

146

** Correlation is significant at the 0.01 level (2-tailed).

There was a positive association between the variables of the study, that is, leadership competency, financial competency, project consultant competency and information technology competency with coefficients $0.636,0.645,0.676$ and 0.622 respectively.

\section{Regression coefficients}

Table 6 Model summary

\begin{tabular}{ccccc} 
Model & R & R Square & Adjusted R Square Std. Error of the Estimate \\
\hline 1 & $.843 \mathrm{a}$ & 0.71 & 0.702 & 0.25333 \\
\hline
\end{tabular}

The value of adjusted R squared was 0.702 implying that $70.2 \%$ of the performance of commercial housing projects in Kiambu County could be explained by internal management competencies.

Table 7 Regression Anova

\begin{tabular}{clccccc}
\hline Model & & Sum of Squares & df & Mean Square & F & Sig. \\
\hline 1 & Regression & 22.208 & 4 & 5.552 & 86.511 & $0.013 \mathrm{~b}$ \\
& Residual & 9.049 & 141 & 0.064 & & \\
& Total & 31.257 & 145 & & & \\
\hline
\end{tabular}


Journal of Entrepreneurship and Project Management

ISSSN 2520-9116 (Online)

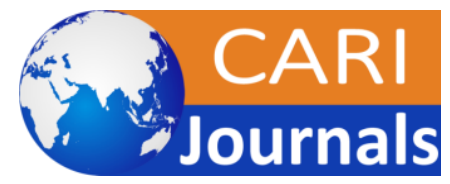

Vol.6, Issue No.1, pp $1-23,2021$

WWW.carijournals.org

The model is significant statistically with $\mathrm{p}$-value $=0.013$ implying that the independent variables (leadership competency, financial competency, project consultant competency, information technology competency) are usable in explaining the independent variable (performance of commercial housing projects).

Table 8 Coefficients of regression

\begin{tabular}{|c|c|c|c|c|c|c|}
\hline \multirow[t]{2}{*}{ Model } & & \multicolumn{2}{|c|}{$\begin{array}{l}\text { Unstandardized } \\
\text { Coefficients }\end{array}$} & \multirow[t]{2}{*}{$\begin{array}{c}\text { Standardized } \\
\text { Coefficients }\end{array}$} & \multirow[t]{2}{*}{$\mathbf{t}$} & \multirow[t]{2}{*}{ Sig. } \\
\hline & & B & $\begin{array}{l}\text { Std. } \\
\text { Error }\end{array}$ & & & \\
\hline \multirow[t]{5}{*}{1} & (Constant) & 0.449 & 0.196 & & 2.295 & 0.023 \\
\hline & $\begin{array}{l}\text { leadership } \\
\text { competency }\end{array}$ & 0.292 & 0.041 & 0.365 & 7.066 & 0.001 \\
\hline & financial competency & 0.247 & 0.042 & 0.322 & 5.935 & 0.011 \\
\hline & $\begin{array}{l}\text { project consultant } \\
\text { competency }\end{array}$ & 0.215 & 0.038 & 0.308 & 5.697 & 0.000 \\
\hline & $\begin{array}{l}\text { information } \\
\text { technology } \\
\text { competency }\end{array}$ & 0.141 & 0.057 & 0.15 & 2.479 & 0.014 \\
\hline
\end{tabular}

Leadership competency with a coefficient of 0.292 ( $p$-value $=0.001)$; financial competency with a coefficient of 0.247 ( $\mathrm{p}$-value $=0.011$ ); project consultant competency with a coefficient of 0.215 $(\mathrm{p}$-value $=0.000)$ and information technology competency with a coefficient of 0.141 ( $\mathrm{p}$-value $=$ 0.014) were found to be significant and relating positively on performance.

The summary of the model is shown in the equation.

Performance of commercial housing projects $(\mathbf{Y})=0.449+0.292 \mathrm{X}_{1}+0.247 \mathrm{X}_{2}+0.215 \mathrm{X}_{3}+$ $0.141 \mathrm{X}_{4}$

Where $\mathrm{X}_{1}$ is the leadership competency, $\mathrm{X}_{2}$ is financial competency, $\mathrm{X}_{3}$ is project consultant competency and $\mathrm{X}_{4}$ is the information technology competency.

\section{CONCLUSION AND RECOMMENDATIONS}

\section{Conclusion}

Leaders in the various commercial housing firms are people who can fully express themselves to demonstrate leadership competency, intelligent and action-oriented, well experienced, possess good planning and communication skills and also aware of the dominance of environment and 
Journal of Entrepreneurship and Project Management

ISSSN 2520-9116 (Online)

Vol.6, Issue No.1, pp $1-23,2021$

$\underline{\text { www.carijournals.org }}$

human resources. Good leadership is the art of influencing others to their maximum performance to accomplish any task, objective or project.

Financial matters in the various commercial housing firms always offer alternatives that do mitigate risks that may occur in the process of various operations. Adoption and involvement of cost control methods in the projects is necessary and this involves consultants having financial literacy knowledge in their operations. The ability to control assets in the projects leads to a high performance.

Consultants having the required consultancy competence eventually lead to success in the projects and organizations operations. Consultants consistently supervise the projects to monitor progress, building technology knowledge and having the ability to draw and design the projects effectively has an effect on the individual performance of commercial housing project organizations.

Commercial housing organizations have adopted an easy to use information technology and are aware of their technology portfolio. Knowledge about novel IT to enable effective IT decisions making and innovation is necessary in the projects. The system to generate quality information needed by in the various projects is as well needful in organizations which impacts performance of the commercial housing projects.

\section{Recommendations}

The commercial housing firms should adopt the various strategic competencies that are useful to an organization to boost the performance of projects in commercial housing. The competencies include leadership and top management skills and financial management. The modern technology in the IT field is useful and should be adopted in the various project firms. Commercial housing firms' excellence in internal management and acquisition of necessary physical and human resources should be an aim for all the registered firms. This is necessary to ensure quality of the projects.

\section{REFERENCES}

Ahsan, K., Ho, M., \& Khan, S. (2013). Recruiting project managers: A comparative analysis of competencies and recruitment signals from job advertisements. Project Management Journal, 44(5), 36-54.

Aigbavboa, C. O., Thwala, W. D., \& Mukuka, M. J. (2014). Construction project delays in Lusaka, Zambia: causes and effects. Journal of Economics and Behavioral Studies, 6(11), 848.

Alaghbari, W. E., Razali A. Kadir, M., Salim, A., \& Ernawati. (2010). The significant factors causing delay of building construction projects in Malaysia. Engineering, Construction and Architectural Management, 14(2), 192-206.

Alias, Z., Zawawi, E. M. A., Yusof, K., \& Aris, N. M. (2014). Determining critical success factors of project management practice: A conceptual framework. Procedia-Social and Behavioral Sciences, 153, 61-69.

Ambale, D., Githui, T., \& Omurwa, M. J. O. (2019). Lender Factors Affecting Residential Mortgage Uptake in Kenya. African Journal of Emerging Issues, 1(12), 17-40. 
Journal of Entrepreneurship and Project Management

ISSSN 2520-9116 (Online)

Vol.6, Issue No.1, pp $1-23,2021$

www.carijournals.org

Amoatey, C. T., Ameyaw, Y. A., Adaku, E., \& Famiyeh, S. (2015). Analysing delay causes and effects in Ghanaian state housing construction projects. International Journal of Managing Projects in Business, 8(1), 198-214.

Armstrong, C.P. (2015) Creating business value through information technology: The effects of the chief information officer and top management team. Ph.D. dissertation, Florida State University

Armstrong, C.P. and Sambamurthy, V. (2011). Information technology assimilation in firms: The influence of senior leadership and IT infrastructure. Information Systems Research, 10, 304-342.

Bãlan, S., \& Vreja, L. O. (2013). The Trompenaars' seven-dimension cultural model and cultural orientations of Romanian students in management. In Proceedings of the 7th International Management Conference" New Management for the New Economy", November 7th-8th, Bucharest, Romania.

Barte, R., (2012). Financial literacy in microenterprises: The case of Cebu Fish vendors Philippines Management Review 2012.Vol: 9.

Bass, B. M. (2010). Leadership and performance beyond expectations. NY: Free Press.

Bredin, K., \& Söderlund, J. (2013). Project managers and career models: An exploratory comparative study. International journal of project management, 31(6), 889-902.

Brière, S., Proulx, D., Flores, O. N., \& Laporte, M. (2015). Competencies of project managers in international NGOs: Perceptions of practitioners. International Journal of Project Management, 33(1), 116-125.

Bucero, A., \& Englund, R. L. (2015, October). Project sponsorship: Achieving management commitment for project success. Project Management Institute.

Burgess, C., \& Bryant, K. (2010). Revenue management-the contribution of the finance function to profitability. International Journal of Contemporary Hospitality Management, 13(3), 144-150.

Chamwada, V. K. (2015). The Effect of Financial Literacy on Financial Performance of Small and Micro Enterprises in Kibera Slums, Nairobi County (Doctoral dissertation, University of Nairobi).

Chan, C. C., Lee, Y. C., Lam, H., \& Zhang, X. M. (Eds.). (2004). Analytical method validation and instrument performance verification. John Wiley \& Sons.

Chandra, N. (2017). Do Project Management Competencies Influence the Project Performance?: An Insight at Philips Healthcare. [Netherlands]:[publisher not identified].]

Chisenga, J. (2006). Information and communication technologies: opportunities and challenges for national and university libraries in Eastern, Central and Southern Africa.

Cohen, W. M. (2010). Fifty years of empirical studies of innovative activity and performance. In Handbook of the Economics of Innovation (Vol. 1, pp. 129-213). North-Holland. 
Journal of Entrepreneurship and Project Management

ISSSN 2520-9116 (Online)

Vol.6, Issue No.1, pp $1-23,2021$

www.carijournals.org

Cohen, W.M. \& Levinthal, D.A. (March 2010), Absorptive capacity: A new perspective on learning and innovation. Administrative Science Quarterly, 35 128-152.

Crawford, L., \& Nahmias, A. H. (2010). Competencies for managing change. International journal of project management, 28(4), 405-412.

Cronbach, L. J. (2011). Coefficient alpha and the internal structure of tests. Psychometrika, 16(3), 297-334.

Dainty, A. R., Cheng, M. I., \& Moore, D. R. (2004). A competency-based performance model for construction project managers. Construction Management and Economics, 22(8), 877-886.

Didenko, I., \& Konovets, I. (2009). Success Factors in Construction Projects: A Study of Housing Projects in Ukraine.

Fisher, R. I., Bernstein, S. H., Kahl, B. S., Djulbegovic, B., Robertson, M. J., De Vos, S., ... \& Stadtmauer, E. A. (2010). Multicenter phase II study of bortezomib in patients with relapsed or refractory mantle cell lymphoma. Journal of clinical oncology, 24(30), 48674874.

Florence, (2014) Effect of competency and communication on project outcomes in.... Available from:

https://www.researchgate.net/publication/265169657_Effect_of_competency_and_comm unication on project outcomes in cities in China [accessed Jun 08 2018].

Gitman, L., \& Zutter, C. (2011). Principles of Managerial Finance, 13 th, Global Edition.

Gluckman, P. D., Hanson, M. A., Cooper, C., \& Thornburg, K. L. (2012). Effect of in utero and early-life conditions on adult health and disease. New England Journal of Medicine, 359(1), 61-73.

Goel, S., \& Elstak, I. (2013). Connecting Algebra and Geometry for Extraneous Roots. Georgia Journal of Science, 71(2), 11.

Groves, R. M., Fowler, F. J., Couper, M. P., Lepkowski, J. M., Singer, E., \& Tourangeau, R. (2009). Survey Methodology. Hoboken. Google Scholar.

Gruden, N. \& Stare, A. (2018). The Influence of Behavioral Competencies on Project Performance. Project Management Journal, 49(3), 98-109.

Hales, C., \& Gooch, S. (2011). Managing engineering design. Springer Science \& Business Media.

Haliso, Y. (2011). Factors affecting information and communication technologies (ICTs) use by academic librarians in Southwestern Nigeria.

Hassan, T. M., \& Thorpe, A. (2014). Modelling information flow during the conceptual and schematic stages of building design. Construction Management \& Economics, 17(2), 155167

Hawajreh, K. M., \& Sharabati, A. (2012). The Impact of Information Technology on Knowledge Management Practices. International Journal of Business, Humanities and Technology, 2(7), 32-46. 
Journal of Entrepreneurship and Project Management

ISSSN 2520-9116 (Online)

Vol.6, Issue No.1, pp $1-23,2021$

www.carijournals.org

Heagney, J. (2016). Fundamentals of project management. AMACOM Div American Mgmt Assn.

Heldman, K. (2015). PMP project management professional exam deluxe study guide: updated for the 2015 Exam. John Wiley \& Sons.

Hwang, B. G., \& Ng, W. J. (2013). Project management knowledge and skills for green construction: Overcoming challenges. International Journal of Project Management, 31(2), 272-284.

Iyer, K. C., \& Jha, K. N. (2015). Factors affecting cost performance: evidence from Indian construction projects. International Journal of Project Management, 23(4), 283-295.

Jha, K. N., \& Iyer, K. C. (2016). Critical factors affecting quality performance in construction projects. Total Quality Management and Business Excellence, 17(9), 1155-1170.

Kahneman, D., \& Tversky, A. (2017). Choices, values, and frames. American Psychologist, 39(4), 341.

Kaifi, B. A., \& Mujtaba, B. G. (2010). Transformational leadership of Afghans and Americans: A study of culture, age and gender. Journal of Service Science and Management, 3(01), 150.

Keen, P.G.W.(2011) Shaping the future: Business design through information technology. Boston: Harvard Business School Press.

Kerzner, H. (2017). Project management metrics, KPIs, and dashboards: a guide to measuring and monitoring project performance. John Wiley \& Sons.

Kibuchi, N., \&Muchungu, P. (2012). The contribution of human factors in the performance of construction projects in Kenya: a case study of construction project team participants in $\begin{array}{lllll}\text { Nairobi. } & \text { Retrieved } & \text { October } & 17, & \text { 2017, }\end{array}$ http://erepository.uonbi.ac.ke:8080/xmlui/handle/123456789/6951

Kiioh, L. K. (2015). Influence of project management leadership on performance of information technology projects: A case of fin-tech Kenya (Doctoral dissertation, Doctoral dissertation, University of Nairobi. Google Scholar).

Kim, G., Shin, B., Kim, K. K., \& Lee, H. G. (2011). IT capabilities, process-oriented dynamic capabilities, and firm financial performance. Journal of the Association for Information Systems, 12(7), 487.

Kimani, K. A. (2015). Impact of Information Technology on Organizational Performance: Case of Population Services Kenya (Doctoral Dissertation, School Of Business, University Of Nairobi).

Kothari, C. R. (2004). Research methodology: Methods and techniques. New Age International.

Kotur, B. R., \& Anbazhagan, S. (2014). The Influence of Education and Work-Experience on the Leadership Styles. Journal of Business and Management, 16(2), 103-110.

Krajewski, L. J., Malhotra, M. K., \& Ritzman, L. P. (2015). Operations management: processes and supply chains. Pearson. 
Journal of Entrepreneurship and Project Management

ISSSN 2520-9116 (Online)

Vol.6, Issue No.1, pp $1-23,2021$

www.carijournals.org

Larson, E. W., \& Gray, C. (2013). Project management: The managerial process with MS project. McGraw-Hill.

Leonard-Barton, D. \& Deschamps, I. (2018). Managerial influence in the implementation of new technology. Management Science, 34, 10 (2008), 1252-1265.

Lepartobiko, W. (2012). Factors that influence success in large construction projects: the case of Kenya Urban Roads Authority projects. M.Sc thesis, Retrieved October 17, 2017

Locke, E.A. and Schweiger, D.M. (2010), Participation in decision-making: One more look. Research in Organizational Behavior, 1 265-339.

Ma, Y., Jeng, M. C., McGaughy, B. W., Wu, L., \& Liu, Z. (2011). U.S. Patent No. 7,933,747. Washington, DC: U.S. Patent and Trademark Office.

Mattimoe, R., \& Seal, W. (2011). Pricing in a service sector context: Accounting and marketing logics in the hotel industry. European Accounting Review, 20(2), 355-388.

Mbachu, J., \& Nkando, R. (2014). Factors constraining successful building project implementation in South Africa. Construction Management and Economics, 25(1), 39-54.

Mbaluka H \& Bwisa H (2013) Delay factors in Construction Projects implementation in the Public Sector: A case study of the Kenya Agriculture Research Institute Construction Projects.

Meyer, R. M., Hayes, L. J., \& Wang, S. (2011). The Patient Care Delivery Model-an open system framework: conceptualization, literature review and analytical strategy. Journal of Clinical Nursing, 20(11-12), 1640-1650.

Mugenda, A. G. (2008). Social science research: Theory and principles. Nairobi: Applied.

Mugenda, A. G. (2013). Qualitative Research Methods.

Mugenda, O. M., \& Mugenda, G. A. (2003). Research methods Quantitative and Qualitative Approaches. Nairobi: ACTS.

Munyoki, S. K. (2014). Factors influencing completion of construction projects; a case of construction projects in Nairobi Kenya (Doctoral dissertation, Doctoral dissertation, University of Nairobi).

Mwai, K. J. (2014). Factors Influencing Project Completion In The Housing Construction Industry, Nairobi County.

Mwambia, D., (2014). The Effect of Financial Literacy on Financial Returns of Miraa Farmers in Meru County. University of Nairobi, MBA Project

Neuman, W. L. (2013). Social research methods: Qualitative and quantitative approaches. Pearson education.

Northouse, P. G. (2007). Leadership: Theory and practice. New York: Sage publications.

Nyangilo, A. O. (2012). An assessment of the organization structure and leadership effects on construction projects' performance in Kenya: a case study of public building projects within Nairobi region, Thesis. University of Nairobi. 
Journal of Entrepreneurship and Project Management

ISSSN 2520-9116 (Online)

Vol.6, Issue No.1, pp $1-23,2021$

www.carijournals.org

Nyariranwge, M. and Oluwayomi, B. (2016), "Impact of project manager's leadership on complex mega infrastructure project performance: a literature review”, 9th CIDB Postgraduate Conference, "Emerging Trends in Construction Organizational Practices and Project Management Knowledge Area". Cape Town, February 1-4

Ogero, D. K. (2014). Influence of Project Management Information System on Project Performance in the Construction Industry: A Case of Nairobi County, Kenya.

Orodho, J. A. (2004). Techniques of writing research proposals and reports in education and social sciences. Nairobi: Masola Publishers.

Papke-Shields, K. E., Beise, C., \& Quan, J. (2010). Do project managers practice what they preach, and does it matter to project success?. International journal of project management, $28(7)$, 650-662.

Pellinen, J. (2003). Making price decisions in tourism enterprises. International Journal of Hospitality Management, 22(2), 217-235.

PMI (2013). A Guide to the Project Management Body of Knowledge (PMBOK Guide). 5rd edition

PMI (2016) Government Extension to the PMBOK_Guide Third Edition. Project Management Institute, Newton Square, PA, USA.

Project Management Institute (PMI). (2008). Project Manager Competency Development Framework, Pennsylvania: Newton Square.

Raymond, E. B. (2016). Learners with mild disabilities: A characteristics approach. Pearson.

Raymond, Louis \& Bergeron, François. (2008). Project management information systems: An empirical study of their impact on project managers and project success. International Journal of Project Management. 26(2). 213-220.

Richardson, C. R., Buis, L. R., Janney, A. W., Goodrich, D. E., Sen, A., Hess, M. L., ... \& Strecher, V. J. (2010). An online community improves adherence in an internet-mediated walking program. Part 1: results of a randomized controlled trial. Journal of medical Internet research, 12(4).

Sambamurthy, N. S., \& Krishnan, P. (2014). U.S. Patent No. 8,904,473. Washington, DC: U.S. Patent and Trademark Office.

Sambamurthy, V., \& Zmud, R. W. (2014). IT management competency assessment: A tool for creating business value through IT. Morristown, NJ: Financial Executives Research Foundation.

Schuessler, S. (2010). Establishing the Synergy between Finance \& Marketing in Lodging Operations.

Silver, M. S. (2015). Decisional guidance: broadening the scope. In Human-Computer Interaction and Management Information Systems: Foundations (pp. 104-133). Routledge.

Silver, M.S. (2015). The information technology interaction model: A foundation for the MBA core course. MIS Quarterly, 19, 3 (2015), 361-390. 
Journal of Entrepreneurship and Project Management

ISSSN 2520-9116 (Online)

Vol.6, Issue No.1, pp $1-23,2021$

www.carijournals.org

Singh, A., Uijtdewilligen, L., Twisk, J. W., Van Mechelen, W., \& Chinapaw, M. J. (2012). Physical activity and performance at school: a systematic review of the literature including a methodological quality assessment. Archives of pediatrics \& adolescent medicine, 166(1), 49-55.

Smith, John B. 2016, Becoming the new technology executive. CIO Canada. 2016, 39-46.

Starkweather, J. A., \& Stevenson, D. H. (2011). PMP® certification as a core competency: Necessary but not sufficient. Project Management Journal, 42(1), 31-41.

Stevenson, D. H., \& Starkweather, J. A. (2010). PM critical competency index: IT execs prefer soft skills. International Journal of Project Management, 28(7), 663-671.

Succar, B., Sher, W. and Williams, A. (2013) 'An integrated approach to BIM competency assessment, acquisition and application', Automation in Construction, 35, pp. 174-189

Svejvig, P., \& Andersen, P. (2015). Rethinking project management: A structured literature review with a critical look at the brave new world. International Journal of Project Management, 33(2), 278-290.

Sweis, R. J., Bisharat, S. M., Bisharat, L., \& Sweis, G. (2014). Factors affecting contractor performance on public construction projects. Life Science Journal, 11(4s), 28-39.

Turner, R. (2016). Gower handbook of project management. Routledge.

Vitale, M.R. (2016).Linking Information Technology and Corporate Strategy: An Organizational View. Proceedings of the seventh International Conference on Information Systems. San Diego, California, 2016, 265-276.

Walker, A. (2015). Project management in construction. John Wiley \& Sons. Crawford, L., Hobbs, B. and Turner, J.R. (2005) Project Categorization Systems. Project Management Institute, Newton Square, PA, USA.

Wangeci, N. E. (2013). Determinants influencing performance of agricultural projects: A case of NALEP projects in Ruiru District, Kiambu County, Kenya.

Young, M. and Conboy, K. (2013) 'Contemporary project portfolio management: Reflections on the development of an Australian Competency Standard for Project Portfolio Management', International Journal of Project Management, 31, pp. 1089-1100

Zhang, F., Zuo, J., \& Zillante, G. (2013). Identification and evaluation of the key social competencies for Chinese construction project managers. International Journal of Project Management, 31(5), 748-759.

Zhang, X., Wu, Y., Shen, L., \& Skitmore, M. (2014). A prototype system dynamic model for assessing the sustainability of construction projects. International Journal of Project Management, 32(1), 66-76. 